\title{
An economic perspective on clearcut harvesting
}

\author{
by Bill Wilson ${ }^{1}$ and Louise Wilson ${ }^{2}$
}

The economic contributions from commercial forestry, measured in trade terms, employment and regional development, are well established. Less understood is the environmental contribution of forestry, provided that forestry is practised in a sustainable manner. Despite the economic and environmental benefits, the social license for commercial forestry is increasingly challenged in terms of access to timber and the conditions placed on access, and in access to major export markets for forest products. Fundamental to addressing these challenges is the utilization of harvesting regimes acceptable to both resource owners and consumers. Clearcut harvesting may be a scientifically reasonable replication of natural disturbance, allowing adequate provision for forest character and structure, but it is the emotional impact of the harvest site that often determines public acceptability.

The institutional setting for commercial forestry is evolving rapidly and is increasingly driven by non-governmental groups that are proving particularly adept with information age tools. This paper will examine the supply and demand factors that are producing the pressure on harvesting practices, the institutional response to these pressures, the physical and financial implications of partial-cut harvesting, and will examine the harvesting norms that have emerged in a number of key softwood producing regions.

Key words: clearcutting, partial-cut harvesting, forest management, forest policy, marketing

La contribution économique de la foresterie industrielle, mesurée en terme d'échanges commerciaux, d'emploi et de développement régional, est bien établie. Par contre, la contribution environnementale de la foresterie, à condition qu'elle soit pratiquée de manière durable, est moins comprise. Malgré les bénéfices économiques et environnementaux, l'étiquette sociale de la foresterie industrielle est de plus en plus remise en question pour ce qui est de l'accès à la matière ligneuse et aux conditions stipulées en matière d'accès, et de l'accessibilité des principaux marchés d'exportation de produits forestiers. À la base de l'étude de ces défis, on retrouve l'utilisation des modes d'exploitation qui soient acceptables autant pour les propriétaires des ressources que pour les consommateurs. La coupe à blanc peut être une réplique adéquate d'une perturbation naturelle, permettant une réserve suffisante pour ce qui est des caractéristiques et de la structure des forêts, mais l'impact émotionnel face à un site exploité détermine souvent le niveau d'acceptabilité du public.

Le cadre institutionnel de la foresterie industrielle évolue rapidement et est de plus en plus dirigé par des groupes non-gouvernementaux qui se sont avérés particulièrement habile avec les outils de l'âge de l'information. Cet article passera en revue les facteurs de l'offre et de la demande qui exercent une pression sur les pratiques de récolte, la réponse institutionnelle à ces pressions, les implications physiques et financières des coupes partielles, et examinera les normes de récolte qui ont été établies dans plusieurs régions productrices de résineux.

Mots-clés : coupe à blanc, coupe partielle, aménagement forestier, politique forestière, mise en marché

\section{Introduction}

The challenge to commercial forestry has a variety of dimensions but certainly a key one is the practice of clearcut harvesting. In this context, clearcutting, one of many forest regeneration options, is "a method of regenerating an even-age stand in which a new age class develops in a fully exposed microclimate after removal of all trees in the previous stand" (SAF 1994). This silviculture system has its roots in German efforts in the 1700 s to mitigate the effects of high-grading on the character and structure of German forests. Clearcutting is one of three classical even-aged silvicultural systems: the other two are shelterwood and seed-tree systems. Partial cutting (i.e., harvesting that is an alternative to clearcutting) involves long-term retention within the stands for uneven-aged management and the related silvicultural systems are single-tree selection and group selection. Partial-cut harvesting is generally adopted to deliver visual, wildlife and/or hydrology objectives.

There are a number of scientifically sound reasons advanced for properly applied clearcut harvesting. These include:

\footnotetext{
${ }^{1}$ Director, Industry, Trade and Economics, Canadian Forest Service, Victoria, BC. E-mail: bwilson@pfc.forestry.ca

${ }^{2}$ Director, Economics Branch, BC Ministry of Employment and Investment, Victoria, BC.

Note: The editors were very saddened to learn that Louise Wilson passed away in January 2001.
}

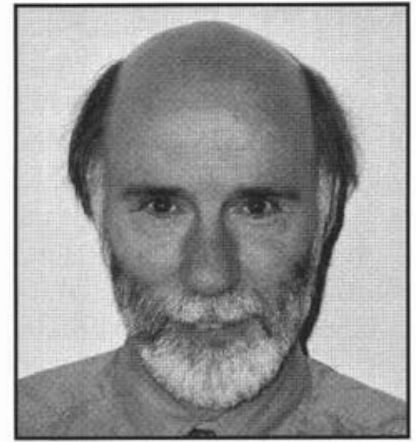

Bill Wilson

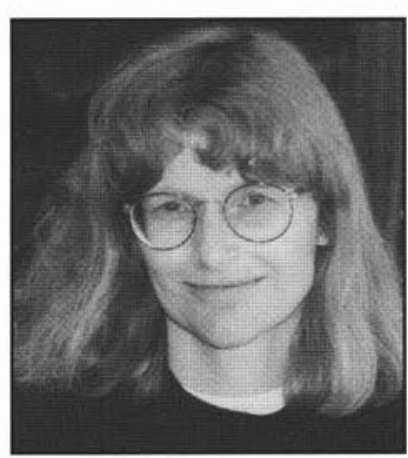

Lovise Wilson clearcutting as a rough proxy for mimicking regeneration practices that occur through natural forest disturbances; creation of temporary conditions for wildlife that benefit from open area and early successional stages (Bolen and Robinson 1995); establishing microclimatic conditions required for regeneration of shade-intolerant species (these include Douglas-fir, lodgepole pine, aspen, white birch, and larch); and removal of stands lacking in preferred quality and character. Clearcutting also provides financial advantages due to scale efficiencies in harvest operations and safer felling conditions. The latter is par- 


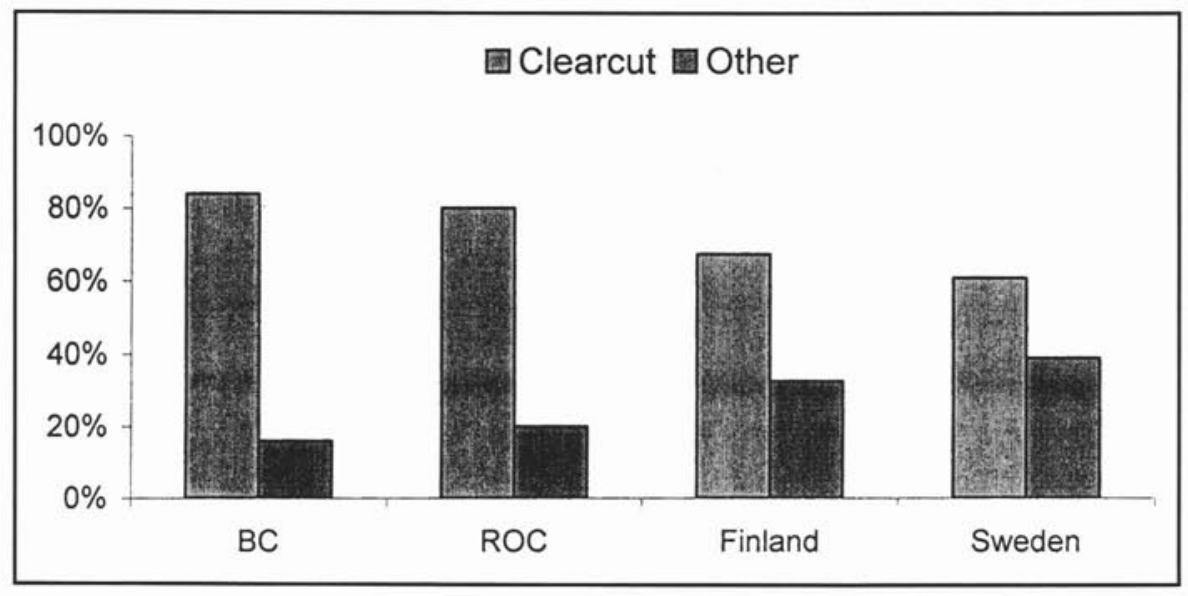

Fig. 1. Silvicuture systems as proportion of harvest.

Sources: Wilson et al. 1999, CCFM 2000, Skogsstyrelsen 2000.

Notes: $\mathrm{ROC}=$ rest of Canada. Sweden is estimated on volume harvested basis.

ticularly significant in old-growth stands or stands damaged by catastrophic weather events.

Because of these advantages, clearcutting is something of the standard silvicultural system in commercial forestry. Clearcutting is the norm in fast-growth plantation forestry where initial commercial thinning from below is often undertaken in iterations to improve timber quality but the sites are eventually clearcut. Both in primary forests and forests in subsequent rotation stages, clearcutting is often the harvesting norm (Fig. 1).

However, despite the considerable advantages, it is apparent that clearcut harvesting is increasingly unacceptable. The environmental legacy (e.g., site disturbance or degradation, habitat disruption or loss, and visual impacts) is not seen as adequately offset by the advantages. Both supply and demand pressures are signalling the need for change. The owners of public forest lands do not want clearcut harvests (there is also public pressure on private timberlands to reduce clearcutting) and retail outlets in Europe and the US are responding to pressure to shift away from supplying products sourced from clearcut forests. In addition, commercial forestry has a wellfunded, committed and effective adversary, the environmental non-governmental organizations (ENGOs). Many ENGOs are stridently opposed to clearcut harvesting and have become influential in setting retail, public and government positions on timber resources-particularly extensive forest management.

Commercial forestry is a significant factor in global commerce (total forest product exports were valued at \$200 billion in 1999), is a major source of direct employment and a basis for regional economic activity. From an environmental legacy perspective it is interesting to note that forest products are relatively attractive in comparison with many other building materials (Koch 1992, Athena 2000). Life-cycle analysis provides encouraging estimations of energy and water requirements for construction with wood versus steel. In addition, wood products contribute significantly lower levels of green house gases than competing products. Forestry, when practised properly, is an inherently renewable resource, an important characteristic, because within the capabilities of current technologies, increased population and wealth predictably generate incremental demands for forest products (Binkley 1998). The issue is one of forest management that secures both economic and environmental benefits while operating within the expectations consistent with social expectations and values.
This paper begins with an overview of the drivers affecting the call for reduced clearcut harvesting (including the supply and demand situation for timber) and the market and institutional factors influencing this emergence. The paper then provides a discussion of factors that determine logging productivity and costs, includes a comparison of alternative silviculture systems, and concludes with a comment on the future forestry situation.

\section{What are the Drivers for Reduced Clearcut Harvesting?}

The underlying factors contributing to public interest in forest harvesting and the call for change are multi-faceted, moderately dynamic and not suprisingly, consistent across many jurisdictions. The demand for forest conservation and modifications in forest operational practices is highly correlated with wealth. Improved individual wealth translates into increased demand for recreational access to forest lands (regardless of whether this is actual use or simply retaining the option of future use) and a reduced willingness to tolerate the negative environmental legacy of extensive resource use. The wealth effect is complemented by improvements in education. An educated public is typically less dependent on direct resource utilization (i.e., as part of the transition from a harvesting/extraction to a service-based economy) and less willing to accept the environmental impacts of extensive forest land resource use. The values shift to conservation and multiple use.

Wealth and education combine to promote the ability and interest to travel. Technical efficiencies have reduced travel costs such that air travel is much more common and with air travel comes a landscape perspective. This elevated vantage has made the public more aware of commercial-scale clearcut activity.

The rapid emergence of high-speed communication capabilities has virtually eliminated time and distance costs. Therefore, harvest activity in coastal British Columbia can be on the nightly news around the globe nearly in real time. The Internet has fuelled the ability of ENGOs to position themselves effectively in the public debate on forest harvesting. Sustainability of commercial forestry is a complex issue involving, among other aspects, values, trade-offs, risks, dynamic factors and passion. Unfortunately, the issue is too often presented in simplistic terms and the facts, although interesting, are often not held to be important. 
Public demographics are often a significant driver. An ageing population in developed economies becomes more supportive of resource conservation and current school populations are working in a curriculum that often reflects stronger environmental values. The current teacher supply is heavily sourced from the previous spike in environmental consciousness, the 1960s. Thus, demographics are supporting the public pressure for reduced clearcutting at both ends of the population.

Public ownership of forest lands is a significant factor contributing to forest operational practices in many jurisdictions (e.g., Canada, US, Sweden, and Finland). The public is increasingly asserting its expectations of resource management and use. Governments respond to these signals. Increasingly companies are also seeking vehicles to integrate meaningfully this public demand into land use planning. Even private landowners are subject to public pressure on what operations Nare acceptable and what provisions are required for wildlife habiitat and visual aesthetics. Fee-simple landowners in the US south¿east yellow pine plantations are regulated to provide habitat for fan endangered bird. Private industrial landowners in the US Pacifnic Northwest are working to protect salmon habitat in an effort to avoid the implementation of federal regulatory requirenments (see http://www.nwr.noaa.gov/1habcon/habweb/ $\infty$ ManTech/refs.htm). Scandinavian industrial forest land owners temper their harvests to satisfy the public's strong commitment to open access lands and non-timber forest products.

Clearly, the ENGOs have played and continue to play a piv$₫$ tal role in the development and deployment of a new forestry Iradigm. The emergence of such groups in the policy arena is not peculiar to forestry and is likely a testimony to, among Finther things, the availability of information, pronounced reductIfons in organizational costs, the complexity of modern social Deconomic structure, and the perceived benefits of focused

Tineir views into public policy. In forestry, the ENGOs have been at the hub of the development and promotion of certification

\section{The Market and Institutional Settings}

The timber demand and supply balance also serves to influence expectations on forest management. In periods of excess supply consumers (or retailers) are in a position to ask for more (e.g., certified wood) without having to pay the full cost incurred in meeting the request. Indeed, excess timber supply is a complementary condition for certification deployment. There is an abundance of timber supply, typically high-cost, and this timber competes for market share in a limited number of markets. The fast-growth pine plantations in the southern hemisphere are expected to approximately double volumes in the next two to three decades based on existing inventories (Fig. 2) and the European supply situation illustrates significant additional potential in terms of annual increment (Fig. 3). This supply situation has encouraged major efforts by high-cost European producers to develop market positions in non-traditional markets. European jurisdictions (mainly Austria, Sweden and Finland) have improved their share of Japanese lumber imports from near zero in 1992 to almost 20\% in 1999 (Fig. 4). The Europeans are also actively developing a presence in the US lumber market: small in relative terms but marginal volumes can have a major price impact (Fig. 5). Medium-term timber supply will, for the most part, exceed demand.

The impetus to secure forest certification is further strengthened by corporate concentration in the forest products retail sector. Production side merger and acquisition activity could also support certification expansion. In the US, an estimated $40 \%$ of US retail forest product sales is controlled by two companies (Home Depot and Lowes) and the Canadian retail sector is increasingly concentrated. Concentration makes the sector more sensitive to ENGO campaigns on timber sources. It reduces campaign costs, raises the campaign profile and creates an image of people versus the big corporate monolith.

Governments have responded to public concern on clearcutting with a variety of guidelines, standards, regulations, policies and operational codes (Wilson and Wang 1999, Wilson et al. 1999). Changes in public sector institutions have produced a good deal of review, scrutiny, dialogue and rancour. In addition, the ENGOs have worked to move the agenda forward through the aggressive promotion of forest certification. The ENGO certification vehicle of choice is the Forest Stewardship Council (FSC) but other sector stakeholders have supported the development of a number of additional certification vehicles. These include the Canadian Standards Association (CSA), Interna-

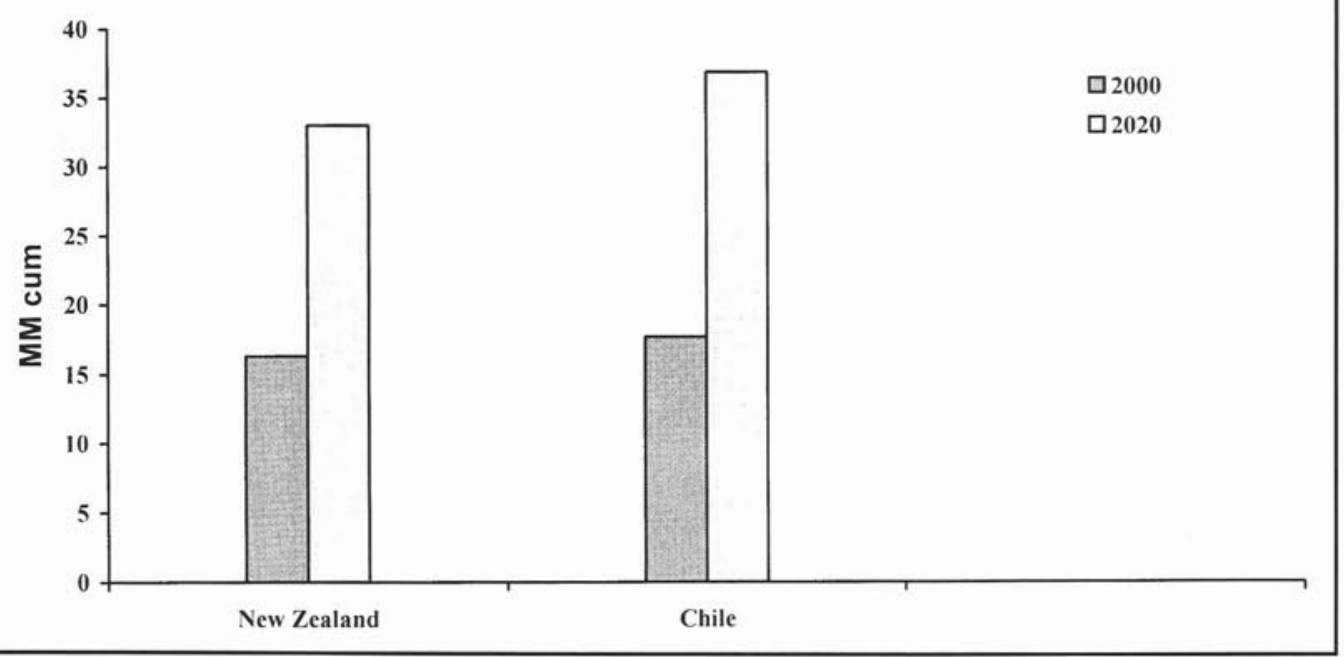

Fig. 2. Select fast-growth pine plantation production volumes.

Source: Wilson et al. 1999. Note: $\mathrm{MM}$ cum $=$ millions of cubic metres. 


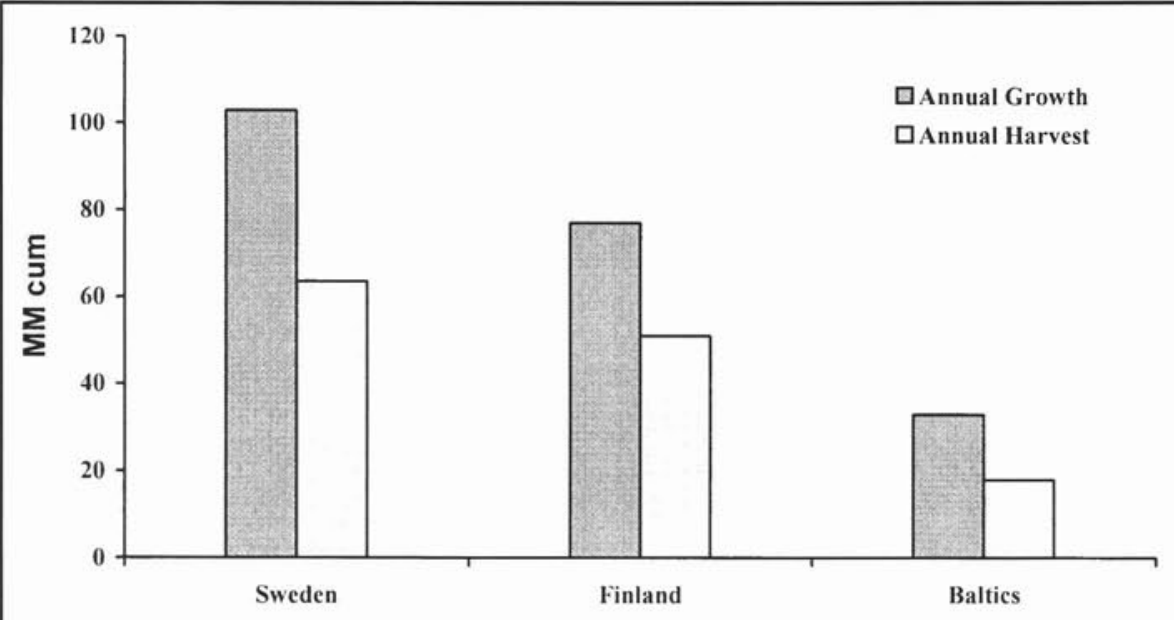

Fig. 3. Select European annual growth and harvest volumes.

Sources: Wilson et al. 1999, ECE/FAO 2000.

Note: $\mathrm{MM}$ cum $=$ millions of cubic metres.

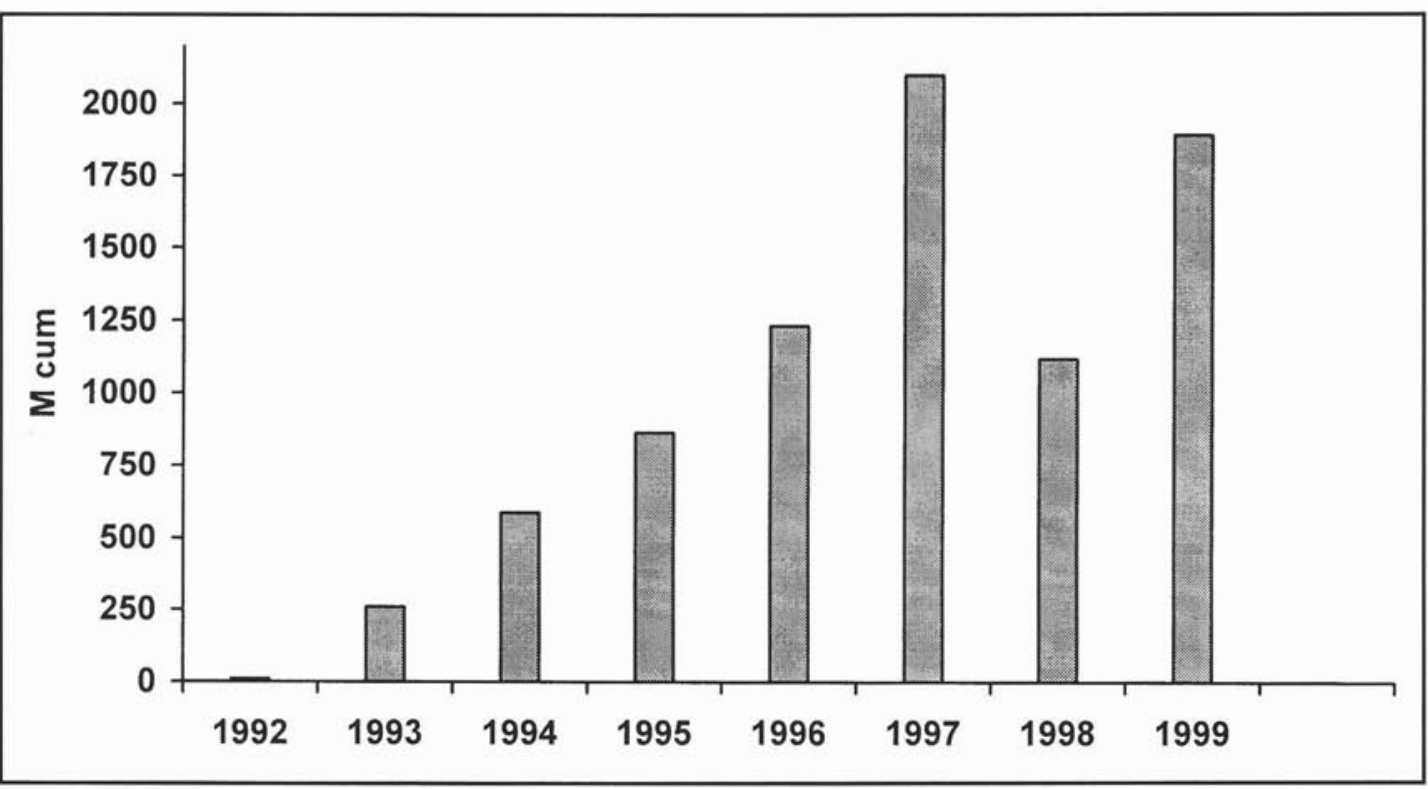

Fig. 4. European lumber exports to Japan. Source: JAWIC 2000. Note: $\mathrm{M}$ cum $=$ thousands of cubic metres.

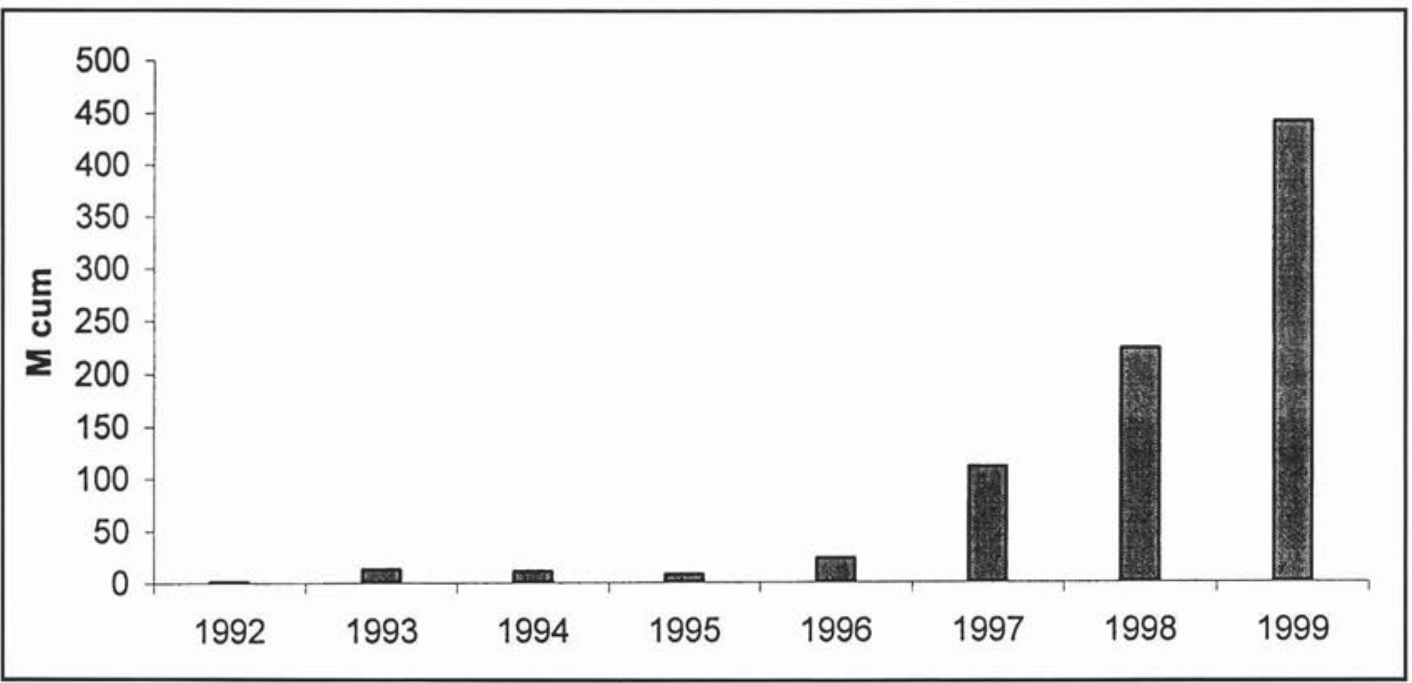

Fig. 5. European lumber exports to the US.

Source: Statistics Canada 2000, USDA 2000.

Note: $\mathrm{M}$ cum $=$ thousands of cubic metres. 
Table 1. A cost comparison of ground-based harvest systems

\begin{tabular}{|c|c|c|c|c|c|c|c|c|}
\hline & \multicolumn{2}{|l|}{ MASS } & \multicolumn{3}{|c|}{ Sicamous } & \multicolumn{3}{|c|}{ Date Creek } \\
\hline & $\% \operatorname{Ret}^{1}$ & $\% \mathrm{CC}^{2}$ & & $\%$ Ret & $\% \mathrm{CC}$ & & $\%$ Ret & $\%$ CC \\
\hline $\mathrm{CC}$ & 0 & 100 & $\mathrm{CC}$ & 0 & 100 & $\mathrm{CC}$ & 0 & 100 \\
\hline GT & 5 & 109 & $\mathrm{P}$ & 67 & 141 & GS & 40 & 180 \\
\hline P & 50 & 110 & GS & 67 & 100 & STS & 70 & 270 \\
\hline SW & 25 & 138 & STS & 67 & 100 & & & \\
\hline
\end{tabular}

Sources: Mitchell 1996, Phillips 1996, Thibodeau et al. 1996. Arnott and Beese 1997.

Note: Includes falling and yarding costs. All case studies were monitored by FERIC.

$1 \%$ Ret is the percentage basal area or ground area retained.

$2 \% \mathrm{CC}$ is the percentage cost of the silviculture system in comparison with clearcutting.

tional Organization for Standardization (ISO), the Sustainable Forestry Initiative (SFI) and the Pan European Forest Certifiication (PEFC). The SFI and PEFC provide encouraging opporItunities for mutual recognition of alternative certification Ðvehicles. Most of these vehicles have a package of criteria and findicators that define and measure sustainable forest management. nCurrently, in Canada about 22 million hectares are certified; तsome carry more than one certification option (about 22 inmillion under ISO, 3 million CSA, 175 thousand SFI, and 28 othousand FSC). $\dot{m}$

\section{Logging Productivity and Cost Factors}

5 No reasonable sector stakeholder can argue with the need videredefine the balance among social, economic and environIngental objectives of forest land use. It is also clear that social Spsessure to reduce the frequency of clearcut harvesting is a key fingredient within this new balance and the public acceptabilitif of commercial forestry. Therefore, in an effort to retain clearcutathing in the range of socially acceptable silvicultural systems, - 0 carcut harvesting may need to be limited to meeting environmental fotjectives such as forest health, structure or character. Finanacial concerns, employment or worker safety are no longer sufficient conditions to warrant clearcut harvests. Clearcut deployOment will need to carefully integrate societal objectives on landscape visuals, ecology, and regeneration.

Forest managers require scientifically sound information on othe feasibility, financial impacts and ecological impacts of harJैvesting options. This section provides a summary of recent research zon the felling and yarding costs of different silvicultural sysgatems from a selection of British Columbia case studies.

The variables that impact on logging productivity and costs acan be aggregated into stand, site and operational groups. EThe stand variables are timber volume per hectare harvested and the volume (or diameter at breast height) per tree harvested. The site variables are the slope and slope profile. The operational variables are harvesting method, hauling distances, external and lateral yarding distances, logs per turn (volume per turn or weight per turn), post-harvest silvicultural methods, crew size and experience, equipment balance and equipment mobility restrictions. Among the operational variables, the harvesting method is the most significant variable affecting productivity and costs.

Three ground-based case studies were examined (see Table 1). The Montane Alternative Silvicultural Systems project (MASS) near Campbell River on Vancouver Island is a highelevation site with a gentle north-facing slope and old-growth forest dominated by amabilis fir (Abies amabilis) and western hemlock (Tsuga heterophylla). The site included clearcutting $(\mathrm{CC})$, green tree retention (GT), small patchcuts (P), and shelterwood (SW) systems. The harvest system was hand fell with excavator forwarding, except for the SW option that used a line/grapple skidder. The CC cost to roadside (not including planning and layout) was estimated at $\$ 7.19 / \mathrm{m}^{3}$. In comparison, alternative silviculture systems ranged from $109 \%$ to $138 \%$ of CC costs (see Table 1). The Sicamous study near Salmon Arm in the BC interior was in 200-year-old subalpine fir (Abies lasiocarpa) and Engelmann spruce (Picea engelmannii). Feller-bunchers and line/grapple skidders were used. Among the harvest systems, group selection (GS) and single tree selection (STS) produced costs equivalent to CC $\left(\$ 6.06 \mathrm{per} \mathrm{m}^{3}\right)$. Both felling and yarding costs were higher for patchcuts $(\mathrm{P})$. The Date Creek project near Hazleton in northern BC, compared CC with GS, and STS in mature and oldgrowth western hemlock and western red cedar (Thuja plicata). The results reported are for hand fell with line/grapple skidding. The STS used horses for the yarding. The CC cost was estimated at $\$ 8.99 \mathrm{~m}^{3}$.

Two "aerial-based" case studies were examined (see Table 2). The first study was cable harvesting at Chamiss Bay near Kyuquot Sound on Vancouver Island. The harvest system for the old-growth amabalis fir and western hemlock on steep slopes was hand felling and a swing yarder with a running skyline. The silviculture systems included CC, strip clearcut (SCC) and variable retention (VR). The CC cost at \$20.97 m3 was two to three times more than ground-based systems in the other regions, illustrating the high cost of coastal operation. SCC and VR systems were about $30-45 \%$ more costly than clearcutting (see Table 2). The second study was at Gregory Creek in the Queen Charlotte Islands. The site was steeply sloped with western hemlock and Sitka spruce (Picea sitchensis). Clearcutting was compared with GS and STS (both latter systems had variations in retention levels). The timber was hand felled and yarded with a Sikorsky Skycrane helicopter. The CC cost, estimated at $\$ 51.69 \mathrm{~m}^{3}$, was not much lower than costs for the GS and STS options.

Although the available cost data does offer encouragement, additional research is required to provide better information on alternatives to clearcutting and on the applicability of results to stands with different physical conditions. The work on cost and productivity must also integrate research on the longerterm impacts of harvesting options on forest dynamics, soil characteristics and production capabilities, hydrology, biological diversity and the provision of suitable microclimate conditions for regeneration. Clearcut harvesting also requires research on 


\begin{tabular}{|c|c|c|c|c|c|}
\hline \multicolumn{3}{|c|}{ Chamiss Bay } & \multicolumn{3}{|c|}{ Gregory Creek } \\
\hline & $\% \operatorname{Ret}^{1}$ & $\% \mathrm{CC}^{2}$ & & $\%$ Ret & $\% \mathrm{CC}$ \\
\hline $\mathrm{CC}$ & 0 & 100 & $\mathrm{CC}$ & 0 & 100 \\
\hline SCC & 50 & 130 & GS1 & 50 & 101 \\
\hline VR1 & 65 & 146 & GS2 & 75 & 104 \\
\hline \multirow[t]{2}{*}{ VR2 } & 70 & 128 & STS1 & 75 & 110 \\
\hline & & & STS2 & 85 & 117 \\
\hline
\end{tabular}

Sources: Krag and Clark 1995, Bennet 1997.

Note: Includes falling and yarding costs. All case studies were monitored by FERIC.

$1 \%$ Ret is percentage basal area or ground area retained.

$2 \% \mathrm{CC}$ is the percentage cost of the silviculture system in comparison with clearcutting.

how to better position and blend openings in order to satisfy public concerns about scenic beauty and forest fragmentation. Recent research on scenic beauty in the US Pacific Northwest suggests that 15 percent retention levels were not perceived to be any different than clearcuts (Ribe 1999). The development and transfer of meaningful information on alternatives to clearcut harvesting is a top priority for maintaining a social licence for commercial forestry.

\section{Conclusions - The Future in Forestry}

The information on global timber supply suggests that, in the medium-term, there will be an excess supply of timber in major markets. This "wall of wood" is a product of built-up inventories in Europe and parts of the US, fast-growth plantation volumes and the emergence of Russian export volumes into Asia. This supply/demand imbalance will be further augmented by technological substitution that serves to bring additional fibre from under-utilized species and non-timber fibres into production. These factors will more than offset societal pressure for reduced harvests in primary forests and provisions for protected forest land.

The forest products industry will continue to consolidate and rationalize. This restructuring is a response to, among other things, pressures to secure economies of scale in commodity production and the lack of additional non-committed timber in the established operating theatres of many companies.

Population demographics are driving the transition from sustainable forest management to ecosystem management and the consequent pressure to reduce or to stop clearcut harvesting. Improvements in communication technology bring increased scrutiny to resource management and support a strong ENGO presence in determining resource use policies and agendas. Institutional change in the form of legislation, policy, regulations, guidelines and prescriptive codes has produced considerable change in forest management and many jurisdictions have moved to significantly reduce or eliminate access to primary timber stands (e.g., US, China, New Zealand). A major component of this reform that is operating in the market place (although it is not market-driven) is the rapid emergence of forest certification in a variety of regional, national and international vehicles. The mutual recognition of national or regional certification vehicles, central to the Pan European Forest Certification system, is an encouraging development for sustainable forest management.

Fundamentally, timber production is a renewable resource and when managed properly the relative environmental legacy is better than many competing products. In assessing environmental options, it is important to factor in the multi-dimensional character of each option (i.e., life-cycle assessment provides additional valuable information among alternatives). Commercial forestry can be environmentally sound provided there is proper management and an appropriate balance of social, ecological and economic objectives. One source of imbalance that must be quickly addressed is the widespread use of clearcut harvesting. The evidence signals that clearcut harvesting is increasingly an unacceptable condition within the required balance. Forest science has provided ample evidence on the environmental reasons for clearcutting. The challenge is to match clearcutting up with the stands that require the option for environmental reasons. In the absence of a better match, public acceptance for any use of clearcut harvesting and for commercial forestry will be further eroded.

\section{Endnotes}

The position developed in this paper was presented at the Canadian Woodlands Forum session on Partial Cutting Practices, held at Kelowna, BC in September, 2000. The authors are grateful to V.J. Nordin for his encouragement to complete this research paper. The views expressed are those of the authors and do not necessarily reflect those of the CFS or the BC government.

\section{References}

Arnott, J. and W. Beese. 1997. Alternatives to clearcutting in BC coastal montane forests. The Forestry Chronicle 73(6): 670-678.

Athena. 2000. Website at http://www.athenaSMI.ca/reports/reports.htm Bennet, D. 1997. Partial cutting in mountainous old-growth forests in coastal British Columbia: harvesting productivity and cost, and residual stand impacts. Unpub. Tech Report. FERIC, Vancouver, BC.

Binkley, C. 1998. Sustainable forestry, the forest profession and forestry education: some lessons from North America. Jour of Sustainable Forestry. 7(1/2): 111-126.

Bolen, E. and W. Robinson. 1995. Wildlife Ecology and Management - 3rd edition. Prentice Hall, Englewood Cliffs, NJ.

Canadian Council of Forest Ministers (CCFM). 2000. Compendium of Canadian forestry statistics. Website at http://nfdp.ccfm.org Japan Wood-Products Information and Research Center (JAWIC). 2000. Wood supply and demand information service. Seattle, WA. Koch, P. 1992. Wood versus non-wood materials in US residential construction: some energy-related global implications. In Wood Product Demand and the Environment. Forest Products Society. pp. 252-265. Madison, WI.

Krag, R. and M. Clark. 1995. Helicopter logging in clearcut, patchcut and single-tree selection harvests: the Queen Charlotte Islands, British Columbia. IUFRO XX World Congress. FERIC Reprint. FERIC, Vancouver, BC. 15 p.

Mitchell, J. 1996. Trial of alternative silviculture systems in southern British Columbia: summary of harvesting operations. Tech Note TN-240. FERIC, Vancouver, BC. 15 p.

Phillips, E. 1996. Comparing silvicultural systems in a coastal montane forest: productivity and cost of harvesting operations. FRDA Report No. 247. Canadian Forest Service, Victoria, BC. 42 p.

Ribe, R. 1999. Regeneration harvests versus clearcuts: public views of the acceptability and aesthetics of Northwest Forest Plan harvest. Northwest Science. 73 (Special Issue). 102-117.

Skogsstyrelsen. 2000. Skogsstatistisk Arsbok 2000. Sveriges officiella statistik. Jonkiping. 345 p.

Society of American Foresters Silviculture Working Group (SAF). 1994. Silviculture terminology. D. Adams, D. Loftis, R. Seymour (eds). Bethesda, MD. 
Statistics Canada. 2000. The World Trade Atlas - Canada Version. Ottawa, ON.

Thibodeau, E., R. Krag and I. Hedin. 1996. The Date Creek Study: productivity of ground-based harvesting methods in the interior cedar-hemlock zone of British Columbia. Special Report No. SR-114. FERIC, Vancouver, BC. 38 p.

United Nations Commission for Europe/Food And Agriculture Organization (ECE/FAO). 2000. Forest resources of Europe, CIS, North America, Australia, Japan, and New Zealand. Geneva Timber and Forest Resource Paper No. 17. UN, Geneva. 445 p.
United States Department of Agriculture (USDA). 2000. Web site at fas.usda.gov/ffpd/wood-circulars

Wilson, B. and S. Wang, 1999. Sustainable forestry: the policy prescription in British Columbia. In A. Yoshimoto and K. Yukutake (eds.). Global Concerns for Forest Resource Utilization: Sustainable Use and Management. pp. 35-45. Kluwer Academic Publishers. London, UK.

Wilson, B., C. van Kooten, I. Vertinsky and L. Arthur (eds.). 1999. Forest Policy: International Case Studies. CABI Publishing, Wallingford, UK. 273 p. 